\title{
Screening and Molecular Identification of Microbiota in Human Oral Cavity
}

\author{
19ohammed Alassiri, 1 Mohamed Abu-Zeid, ${ }^{1}$ Mohammed Zini, ${ }^{1}$, 2 Mohamed Morsi M. Ahmed \\ ${ }^{1}$ Department of Biological Sciences, Faculty of Sciences, P.O. Box 80203, King Abdulaziz University, Jeddah City, 21589, Kingdom of Saudi Arabia. \\ ${ }^{2}$ Nucleic Acids Research Department, Genetic Engineering and Biotechnology Research Institute (GEBRI), Mubarak City for Scientific Research and \\ Technology Applications. Alexandria City, Egypt.
}

Correspondence Author: Mohammed Alassiri, Department of Biological Sciences, Faculty of Sciences, P.0. Box 80203, King Abdulaziz University, Jeddah City, 21589, Kingdom of Saudi Arabia.

Received date: 12 August 2018, Accepted date: 10 December 2018, Online date: 25 December 2018

Copyright: (C) 2018 Mohammed Alassiri et al., This is an open-access article distributed under the terms of the Creative Commons Attribution License, which permits unrestricted use, distribution, and reproduction in any medium, provided the original author and source are cre dited.

\begin{abstract}
Since oropharynx is very important, we need to make sure that the oropharynx does not contain microbes. The present study aims to detect and identify bacteria in the microbiota of human saliva using Gram phenotypes and molecular methods using 16S rRNA gene sequencing. Metagenomics sequencing will be performed to extract complete DNA from samples. The human oral cavity can be exposed to various types of environmental microorganisms that are inhaled through the air, drinking water and food. An oral cavity is a place for synanthropic bacteria, some of which (for example, Neisseria spp., A. actinomycetemcomitans, P. gingivalis, P. intermedia, T. forsythensis (previously Bacteroides forsythus) and T. denticola. \& Streptococcus.). May cause illness when entering other areas of the body. In healthy people, flora inhibits colonization by invading microorganisms by altering the pH, producing bacteriocins and mechanically blocking mucosal surfaces. Screening and molecular identification of microbiota in human oropharynx is an important issue as noted in this study on healthy subjects, some species are site specific at one or multiple sites, while other species are subject specific. As much as $60 \%$ of the species detected are not presently cultivable. By using culture-independent molecular methods, we previously detected over 500 species or phylotypes in subgingival plaque of healthy subjects and subjects with periodontal diseases Overall, there are still more species to be discovered, although the number of new species is beginning to reach saturation.It is so important to fully define the human microflora of the healthy human oral cavity before we can understand the role of bacteria in human oral disease and problems.
\end{abstract}

Key words: Molecular, PCR, Microbiota, Oral cavity, 16s rRNA, DNA technology, infection

\section{INTRODUCTION}

The human oropharynx is permanently exposed to different types of environmental microbes, mainly inhaled air, ingested food, and water. The oral cavity of humans can be exposed to different types of environmental microorganisms, which are inhaled by air, drinking water, and ingested foods. An oral cavity is a right place for commensal microbes, some of which (e.g., Neisseria Spp. \& Streptococcus spp.) Can cause diseases when they enter other parts of the body. In healthy people, normal flora inhibits colonization by invading organisms by altering $\mathrm{pH}$, generating bacteriocins and creating a mechanical barrier that blocks adhesion to mucosal surfaces.

The oropharynx is primarily a tank many viruses, including HIV, HPV, and Epstein-Barr, associated with carcinoma of the oropharynx, molecular and genetic methods to date already practiced in study bacterial species of the microbiota of the oral cavity. To simultaneously examine a wide range of bacterial species, standard PCR amplification using primers that point to the same $16 \mathrm{~S}$ rRNA sealed region is generally used. In any case, because of the race of the PCR when using this plan, only the DNA of the majority of the species is amplified at the expense of the DNA of the less critical species. The development of DNA markers and molecular biology techniques is a fundamental tool for applications in genomic studies. This has also created new opportunities for genetic markers, genetic enhancement, and animal marker-assisted selection. In the last 20 years, DNA markers have led to the considerable genetic improvement of farm animals Recent developments in DNA techniques have revealed a substantial genetic polymorphism in DNA sequences and used as a marker to assess the genetic basis of observed phenotypic variation. Markers indicating changes in DNA are called molecular markers.

PCR has become an essential tool with many molecular DNA studies, including DNA detection polymorphism (fingerprint), individual trait binding genotyping and mapping. Genome. In addition to microbial methods, sequencing of 16S rRNA genes and RAPD methods are essential for molecular diagnostics. Using a set of unplanned simple primers RAPD, it is likely that polymorphism can be used in DNA studies. The present study is aimed at the detection and identification of microbes in the microbiota of human saliva using molecular methods using 16S rRNA gene sequencing.

Periodontal problems, mixed multimicrobial infection, are considered to be the primary disease of the oral cavity.

This can be caused by many types of microbes, such as F. nucleatum, A. actinomycetemcomitans, P. gingivalis, Prevotella intermedia, Tannerella forsythensis (formerly Bacteroides forsythus) [1] and Treponema denticola.

Traditional cultural-dependent methods limit the diagnosis of the microbiota in the human oral cavity; thus, more periodontal diseases, mixed multimicrobial infections are the main problems and diseases of the oral cavity; thus, many oral bacteria remain untreated and uncharacteristic. Therefore, studies of organisms responsible for diseases of the oral cavity, including periodontal diseases, are generally limited to cultivated species, such as pathogens, as previously 
indicated. Huge no. Uncultured microorganisms in the mouth can be associated with periodontal disease. Currently, the best available form for determining the diversity of microbes without culture depends on DNA extraction from the target medium, PCR amplification of the rRNA gene, cloning of amplicons in E. coli, and the sequence of studies of cloned 16SrRNA genes of the gene [2].

Cultural-independent methods have already used to define the variety of spirochetes in the subgingival region of subjects with various periodontal diseases with 2 healthy and 1 adult periodontitis, three acute necrotizing ulcerative gingivitis, severely resistant periodontitis and HIV periodontitis, and uncultured and cultured Treponema in case of diseases) [3]. Here we discuss the relationship between periodontal problems and the oropharynx microbiota, plus untreated microorganisms.

The main objective for this study is to do a screening and molecular identification of microbiota In human oral cavity.

\section{Human oral cavity spirochetes}

Correlated with gingivitis flower bacteria [4] [5] and periodontitis [6] have already been studied.

Spirochetes are the predominant organisms identified to increase the number of periodontal sites among the flu bacteria of the oral cavity. While the relationship between periodontitis and oral treponema was emphasized. Clinically, oral Treponema culture was limited due to the sensitivity to oxygen of the unusual nutritional needs of these organizations and the long-term culture [7] [8]. The following species cultivated by Treponema orally were tested: Treponema amylovorum [9], T. denticola [10], T. lecithinolyticum [11], T. maltophilum [12], T. medium [13] [14] T. parvum [15], T. pectinovorum [16], T. putidum [17], T. socranskii [18] and OT. Vincentii. (The last Treponema was not confirmed in the published peer reviewed). However, it was published in the systematic bacteriology of the Berg Guide [19] and is widely used. These types are divided into two groups based on carbohydrate fermentation. The oral saccharolytic treponemas cover 6 species (T. amylovorum T. lecithinolyticum T. maltophilum T. parvum, T. and T. pectinovorum socranskii), and oral treponema oralésaccharolytiques contains four types (T. denticola, T. Wednesday T. putidum, and OT. VincentiiÕ).

Pasteur et al. [20] reported on the phylogeny of cultivated oral treponema isolated by Robert Smibert (Blacksburg Virginia Polytechnic Institute, Virginia, USA). They suggested 3 new species (Smibert-2 Treponema spirochete Smibert-3 and Treponema Smibert-5) based on the comparison of the sequences of 16S rRNA genes. Treponema Smibert-2 was considered as a new species, Treponema parvum [15]. Taxonomic oral spirochetes were discussed in a review article [21]. Among cultivated oral treponemas, T. denticola often identified severe infection sites in patients with periodontitis [22], and many studies have tried to figure out the role of T. denticola in periodontitis [23] [24] [25]. While T. socranskii are regularly isolated from subgingival specimens of plaque with periodontitis with to T. denticola, it is so difficult to cultivate and recognize [26] [27]. The PCR method can be used to identify and recognize T. socranskii [28]. This method is a fast and reliable way to differentiate T. socranskii other cultivations by treponema and oral. Takeuchi et al. [29] used this method to recognize T. socranskii T. denticola and P. gingivalis PCR and to explain the relation between the severity of the periodontal clinical parameters and the presence of these organisms. Their results suggest that $\mathrm{T}$. socranskii $\mathrm{T}$. denticola and $\mathrm{P}$. gingivalis were associated with the severity of destruction of the periodontal tissue. Also, analysis using RFLP (restriction fragment length polymorphism) of the 16SrARN gene amplified by PCR already used to differentiate 3 subspecies of T. socranskii [28]. Newly, the relation between $\mathrm{T}$. socranskii subspecies.

Oral and periodontal infection has been demonstrated [30] [31]. The PCR analysis-RFLP of the 16S rRNA gene was also used to differentiate the treponemas of the oral cavity cultivated, including denticola T., T. medium, pectinovorum T., T. socranskii and T. vincentii [32]. Also, a specific PCR located in species was used to detect T. amylovorum T. denticola, maltophilum T., T. medium, pectinovorum T., T. socranskii, and OT. Vincent-tiiÕ in dental plates [33].

\section{Quantification \& detection of periodontopathic bacteria}

The relation between the periodontal state \& the occurrence of recognition of suspicious periodontal pathogens was fully estimated using PCR of the 16S rRNA gene [34-38]. These results recommend that some species are powerfully related with periodontitis. To understand the etiological role of these bacteria, accurate calculations of periodontal pathogens in clinical specimens (subgingival plaque and saliva) are necessary. The conventional PCR method (final PCR) identifies the plateau reaction phase but is not suitable for quantifying pathogens. On the other hand, the real-time PCR techniques allows observing the exponential phase. This method allows you to detect and quantify microorganisms in clinical specimens quickly. Real-time PCR (TaqMan system) was 1st used to quantify T. forsythensis in the subgingival plaque. [39] This system allowed us to determine both the total number of bacterial cells and the density of P. gingival in the sample plates [40]. Also, real-time PCR using SYBR Green Colorant and Light Cycler (Roche Diagnostics, Mannheim, Germany) was 1st used to detect and calculate periodontal bacteria such as A. actinomycetemcomitans, P. gingivalis, T. forsythensis, T. denticola and T. socranskii, in subgingival plaques and saliva specimens [41]. Using the Light Cycler method, you can determine the value no. periodontal bacteria in less than an hour (A. actinomycetemcomitans: 40 min., P. gingivalis: $34 \mathrm{~min}$., T. forsythensis: $40 \mathrm{~min}$., T. denticola: $32 \mathrm{~min}$., T. socranskii: $46 \mathrm{~min}$.). Maeda et al. [42] recommended that there was no significant difference between the chemistry of TaqMan and SYBR Green in their specificity. Now the detection and quantification of periodontal bacteria by real-time PCR is widespread in this area, and many researches have shown the usefulness of real-time PCR [43-52]. We expect that real-time PCR technology will be an indispensable technique in the future for the diagnosis of periodontal problems, evaluation of treatment and prognostic solutions.

\section{Species list of bacteria in ecosystems of the microbial complex using checkerboard DNA-DNA hybridization}

It is essential to conduct large-scale studies of microbiologically complex ecosystems using generally accepted methods in microbiology. The PCR method mentioned above is not particularly suitable for a considerable step test. Samples for large no. many species.

Molecular identification methods in new forms of the target probe, such as a chessboard for DNA-DNA hybridization, allow counting a large number of species on a large number of samples. [53]. the method of hybridization of DNA-DNA in a chessboard was 1st defined in 1994 by Socransky et al. [54]. Using 40 species-specific DNA-DNA hybridization probes for the detection of bacteria in the oral cavity, it was found that the subgingival plaque contains species in various complexes [55]. Socransky et al. [55] found five main complexes using cluster studies (Table 1). The red complex, containing P. gingivalis, T. forsythensis, and T. denticola, showed a closed connection with periodontal disease, mainly with bleeding and depth of sounding. A DNA-DNA hybridization method in a chessboard has been widely used to test the microbial composition of supraorbital and subgingival plaque in healthy and periodontitis subjects [56] [57], the level of microbiota in saliva, the relationship with periodontal status [58], the relationship between cigarette smoking and the subgenomic microbiota [59] [60], differences between the subgingival microbiota among subjects from different geographic locations [61], the relationship between ethnic /racial group, occupational status and type of periodontal disease [62] and the consequences of various periodontal therapies [63] [64]. Recently it has been reported that DNADNA hybridization in a chessboard is useful for enumerating bacterial species in microbiologically complex systems [53]. This method is fast, sensitive and relatively inexpensive. It overcomes many of the limitations of culture-based approaches. Pasteur et al. [65] developed a PCR-based hybridization protocol for differentiating oral streptococcal species, which are very closely related phylogenetically. Based on these methods, a DNA chip will be developed shortly.

A variety of bacteria in the oral cavity 16 was first used in 1994 to determine the genetic diversity of the treated and uncultured spirochaetes in the gum fissure of a patient with severe periodontitis Choi et al. [66]. These researchers found that the clones were divided into 23 groups of approximately 1 to $2 \%$. Their results point to an unexpected variety of oral treponemas in one patient. This method was then applied to analyze the diversity of asbuharolithic species of Eubacterium [67]. Also, Kroes et al. [68] used this method to characterize the degree of the bacterial method in the slit gap of a person. Although the population in question is small, Sakamoto et al. [69] also used this method to compare the oral microbiota in the saliva of 2 patients with periodontitis and the subject of good periodontal health. There was no clonal sequence associated with the periodontal bacteria in the saliva of a healthy subject, whereas no. Periodontal pathogens such as Campylobacter rectus, P. intermedia, P. gingivalis, and T. socranskii were found in the saliva of patients with periodontitis. Also, several uncharacterized and non-essential microorganisms were found. Subsequently, Paster et al. showed that the predominant subgingival bacterial community consists of 347 species or phylotypes, based on an analysis of $252216 \mathrm{~S}$ rRNA clones, and estimates the total no. of species in the oral cavity of about 500 species. A similar technique was also used to compare bacteria found in children with severe caries with those found in children without cavities [70], and to determine the types and phylotypes common in advanced lesions of children with noma [71]. According to the latest report [72], it is estimated that more than 700 species of bacteria (including phylotypes) live in the oropharynx, and more than half of them cannot be culturing. 


\section{CONCLUSION}

Currently, with the improvement of biotechnology, the progression, and initiation, as well as the mechanism of periodontitis, are becoming so clear. As independent methods of cultivation, a variety of microbiota in the human oral cavity and the presence of a large number of unorganized microorganisms, which are presumably periodontal pathogens, periodontal pathology studies, and oral cavity, human microbiota is transferred to a new achievement. Using the sequence info. of the 16SrRNA gene obtained, he probably detects identified not only oral cavity types but also new recognized non-cultural species (phylotypes) directly in clinical specimens. The Human-Oral-Microbe-Identification-Microarray (HOMIM) slide system, which identifies the majority of the 600 species found in the oropharynx, [73] is currently being expanded. The microchip must be adapted to the study for the simultaneous study of the roles of most microbes existing in the field of oropharyngeal problems. Independent methods of cultivation defined to determine the etiology of periodontal disease.

The main conclusion is that it is so important to do a full definition of the human microbiota of the healthy human oropharynx before understanding the role of microbe in human oral disease and problems.

The authors declare that there are no conflicts of interests.

\section{CONFLICT OF INTERESTS}

\section{ACKNOWLEDGMENT}

This effort powered by King Abdulaziz City for Sciences and Technologies (KACST) in the Saudi Arabia 1-17-01-009-0025. Also, the authors acknowledge assistance from Sciences \& Technology Unit, Deanship of Scientific Research, Deanship of Graduate Studies, and acknowledge support from the Dept. of Biology, Faculty of Sciences, King Abdulaziz University (KAU), Jeddah City, KSA.

\section{REFERENCES}

1. Sakamoto M, Suzuki M, Umeda M, Ishikawa I, Benno Y, 2002. Reclassification of Bacteroides forsythus (Tanner et al. 1986) as Tannerella forsythensis corrig., gen. nov., comb. nov. Int J Syst Evol Microbiol. 52:841-849.

2. Olsen GJ, Lane DJ, Giovannoni SJ, Pace NR, 1986. Microbial ecology and evolution: a ribosomal RNA approach. Annu Rev Microbiol. 40:337-365.

3. Dewhirst FE, Tamer MA, Ericson RE et al, 2000. The diversity of periodontal spirochetes by 16S rRNA analysis. Oral Microbiol Immunol. 15:196-202.

4. Moore LVH, Moore WEC, Cato EP et al, 1987. Bacteriology of human gingivitis. J Dent Res. 66:989-995.

5. Moore WEC, Holdeman LV, Smibert RM et al, 1984. Bacteriology of experimental gingivitis in children. Infect Immun. 46:1-6.

6. Moore WEC, Holdeman LV, Smibert RM, Hash DE, Burmeister JA, Ranney RR. Bacteriology of severe periodontitis in young adult humans. Infect Immun, 1982. 38:1137-1148.

7. Miller JN, Smibert RM, Norris SJ. The genus Treponema. In: Balows A, Tru“ per HG, Dworkin M, Harder W, Shleifer KH, eds, 1992. The prokaryotes, 2nd edn. New York: Springer-Verlag. 3537-3559.

8. Smibert RM. Anaerobic spirochetes. In: Balows A, Hausler WJ Jr, Herrmann KL, Isenberg HD, Shadomy HJ, eds, 1991. Manual of clinical microbiology, 5th edition. Washington DC: American Society for Microbiology. 572-578.

9. Wyss C, Choi BK, Schu“ pbach P, Guggenheim B, Go“ bel UB, 1997. Treponema amylovorum sp. nov., a saccharolytic spirochete of medium size isolated from an advanced human periodontal lesion. Int J Syst Bacteriol. 47:842-845.

10. Chan ECS, Siboo R, Keng T et al, 1993. Treponema denticola (ex Brumpt 1925) sp. nov., nom. rev. and identification of new spirochete isolates from periodontal pockets. Int J Syst Bacteriol. 43:196-203.

11. Wyss C, Choi BK, Schu" pbach P, Moter A, Guggenheim B, Go“ bel UB, 1999. Treponema lecithinolyticum sp. nov., a small saccharolytic spirochaete with phospholipase $A$ and $C$ activities associated with periodontal diseases. Int J Syst Bacteriol. 49:1329-1339.

12. Wyss C, Choi BK, Schu“ pbach P, Guggenheim B, Go" bel UB, 1996. Treponema maltophilum sp. nov., a small oral spirochete isolated from human periodontal lesions. Int J Syst Bacteriol. 46:745-752.

13. Umemoto T, Nakazawa F, Hoshino E, Okada K, Fukunaga M, Namikawa I, 1997. Treponema medium sp. nov., isolated from human subgingival dental plaque. Int J Syst Bacteriol. 47:67-72.

14. Nakazawa F, Hoshino E, Fukunaga M et al, 2003. Amended biochemical characteristics and phylogenetic position of Treponema medium. Oral Microbiol Immunol. 18:127-130.

15. Wyss C, Dewhirst FE, Gmu r R et al, 2001. Treponema parvum sp. nov, a small, glucuronic or galacturonic acid-dependent oral spirochaete from lesions of human periodontitis and acute necrotizing ulcerative gingivitis. Int J Syst Evol Microbiol. 51:955-962.

16. Smibert RM, Burmeister JA, 1983. Treponema pectinovorum sp. nov. isolated from humans with periodontitis. Int J Syst Bacteriol. 33:852-856.

17. Wyss C, Moter A, Choi BK et al, 2004. Treponema putidum sp. nov., a mediumsized proteolytic spirochaete isolated from lesions of human periodontitis and acute necrotizing ulcerative gingivitis. Int J Syst Evol Microbiol. 54:1117-1122.

18. Smibert RM, Johnson JL, Ranney RR, 1984. Treponema socranskii sp. nov., Treponema socranskii subsp. socranskii subsp. nov., Treponema socranskii subsp. Buccale subsp. nov. \& Treponema socranskii subsp. paredis subsp. nov. isolated from the human periodontia. Int J Syst Bacteriol. 34:457-462.

19. Smibert RM, 1984. Genus III. Treponema Schaudinn 1905, 1728AL. In: Krieg NR, Holt JG, eds. Bergey's manual of systematic bacteriology, Vol. 1. Baltimore: Williams \& Wilkins. 49-57.

20. Paster BJ, Dewhirst FE, Coleman BC, Lau CN, Ericson RL, 1998. Phylogenetic analysis of cultivable oral treponemes from the Smibert collection. Int J Syst Bacteriol, 48:713-722.

21. Chan ECS, McLaughlin R, 2000. Taxonomy and virulence of oral spirochetes. Oral Microbiol Immunol, 15:1-9.

22. Riviere GR, Elliot KS, Adams DF et al, 1992. Relative proportions of pathogen-related oral spirochetes (PROS) and Treponema denticola in supragingival and subgingival plaque from patients with periodontitis. J Periodontol, 63:131-136.

23. Ding Y, Uitto VJ, Haapasalo M et al, 1996. Membrane components of Treponema denticola trigger proteinase release from human polymorphonuclear leukocytes. J Dent Res, 75:1986-1993.

24. Ishihara K, Okuda K, 1999. Molecular pathogenesis of the cell surface proteins and lipids from Treponema denticola. FEMS Microbiol Lett, 181:199-204.

25. Simonson LG, Goodman CH, Bial JJ, Morton HE, 1988. Quantitative relationship of Treponema denticola to severity of periodontal disease. Infect Immun, 56:726-728.

26. Koseki T, Ishikawa I, Umeda M, Benno Y, 1995. Characterization of oral treponemes isolated from human periodontal pockets. Oral Microbiol Immunol, 10:271-277.

27. Sakamoto M, Koseki T, Umeda M, Ishikawa I, Benno Y, Nakase T, 1999. Phylogenetic analysis of saccharolytic oral treponemes isolated from human subgingival plaque. Microbiol Immunol, 43:711-716.

28. Sakamoto M, Takeuchi Y, Umeda M, Ishikawa I, Benno Y, Nakase T, 1999. Detection of Treponema socranskii associated with human periodontitis by PCR. Microbiol Immunol, 43:485-490.

29. Takeuchi Y, Umeda M, Sakamoto M, Benno Y, Huang Y, Ishikawa I, 2001. Treponema socranskii, Treponema denticola, and Porphyromonas gingivalis are associated with severity of periodontal tissue destruction. J Periodontol, 72:1354-1363.

30. Hutter G, Schlagenhauf U, Valenza G et al, 2003. Molecular analysis of bacteria in periodontitis: evaluation of clone libraries, novel phylotypes and putative pathogens. Microbiology, 149:67-75.

31. Paster BJ, Boches SK, Galvin JL et al, 2001. Bacterial diversity in human subgingival plaque. J Bacteriol, 183:3770-3783.

32. Sato T, Kuramitsu HK, 1999. Restriction fragment-length polymorphism analysis of 16S ribosomal RNA genes amplified by polymerase chain reaction for rapid identification of cultivable oral treponemes. Oral Microbiol Immunol, 14:117-121. 
33. Willis SG, Smith KS, Dunn VL, Gapter LA, Riviere KH, Riviere GR, 1999. Identification of seven Treponema species in health- and disease-associated dental plaque by nested PCR. J Clin Microbiol, 37:867-869.

34. Ashimoto A, Chen C, Bakker I, Slots J, 1996. Polymerase chain reaction detection of 8 putative periodontal pathogens in subgingival plaque of gingivitis and advanced periodontitis lesions. Oral Microbiol Immunol, 11:266-273.

35. Mayanagi G, Sato T, Shimauchi H, Takahashi N, 2004. Detection frequency of periodontitis-associated bacteria in subgingival and supragingival plaque of periodontitis and healthy subjects. Oral Microbiol Immunol. 19:379-385.

36. Takeuchi Y, Umeda M, Ishizuka M, Huang Y, Ishikawa I, 2003. Prevalence of periodontopathic bacteria in aggressive periodontitis patients in a Japanese population. J Periodontol. 74:1460-1469.

37. Umeda M, Chen C, Bakker I, Contreras A, Morrison JL, Slots J, 1998. Risk indicators for harboring periodontal pathogens. J Periodontol. 69:1111-1118.

38. Umeda M, Miwa Z, Takeuchi Y et al, 2004. The distribution of periodontopathic bacteria among Japanese children and their parents. J Periodont Res. 39:398-404.

39. Shelburne CE, Prabhu A, Gleason RM, Mullally BH, Coulter WA, 2000. Quantitation of Bacteroides forsythus in subgingival plaque. Comparison of immunoassay and quantitative polymerase chain reaction. J Microbiol Methods. 39:97-107.

40. Lyons SR, Griffen AL, Leys EJ, 2000. Quantitative real-time PCR for Porphyromonas gingivalis and total bacteria. J Clin Microbiol. 38:2362-2365.

41. Sakamoto M, Takeuchi Y, Umeda M, Ishikawa I, Benno Y, 2001. Rapid detection and quantification of five periodontopathic bacteria by real-time PCR. Microbiol Immunol. 45:39-44.

42. Maeda H, Fujimoto C, Haruki Y et al, 2003. Quantitative real-time PCR using Taq-Man and SYBR Green for Actinobacillus actinomycetemcomitans, Porphyromonas gingivalis, Prevotella intermedia, tetQ gene and total bacteria. FEMS Immunol Med Microbiol. 39:81-86.

43. Asai Y, Jinno T, Igarashi H, Ohyama Y, Ogawa T, 2002. Detection and quantification of oral treponemes in subgingival plaque by real-time PCR. J Clin Microbiol. 40:3334-3340

44. Boutaga K, van Winkelhoff AJ, Vandenbroucke- Grauls CMJE, Savelkoul PHM, 2003. Comparison of real-time PCR and culture for detection of Porphyromonas gingivalis in subgingival plaque samples. J Clin Microbiol. 41:4950-4954.

45. Kawada M, Yoshida A, Suzuki N et al, 2004. Prevalence of Porphyromonas gingivalis in relation to periodontal status assessed by real-time PCR. Oral Microbiol Immunol. 19:289-292.

46. Kuboniwa M, Amano A, Kimura RK et al, 2004. Quantitative detection of periodontal pathogens using real-time polymerase chain reaction with TaqMan probes. Oral Microbiol Immunol. 19:168-176.

47. Morillo JM, Lau L, Sanz M, Herrera D, Silva A, 2003. Quantitative real-time PCR based on single copy gene sequence for detection of Actinobacillus actinomycetemcomitans and Porphyromonas gingivalis. J Periodont Res. 38:518-524.

48. Nonnenmacher C, Dalpke A, Mutters R, Heeg K, 2004. Quantitative detection of period ontopathogens by real-time PCR. J Microbiol Methods 59:117-125.

49. . Suzuki N, Yoshida A, Saito T, Kawada M, Nakano Y, 2004. Quantitative microbiological study of subgingival plaque by real-time PCR shows correlation between levels of Tannerella forsythensis and Fusobacterium spp. J Clin Microbiol. 42:2255-2257.

50. Yoshida A, Suzuki N, Nakano Y, Oho T, Kawada M, Koga T, 2003. Development of a 5\& fluorogenic nuclease-based real-time PCR assay for quantitative detection of Actinobacillus actinomycetemcomitans and Porphyromonas gingivalis. J Clin Microbiol. 41:863-866.

51. Yoshida A, Kawada M, Suzuki N et al, 2004. TaqMan real-time polymerase chain reaction assay for the correlation of Treponema denticola numbers with the severity of periodontal disease. Oral Microbiol Immunol. 19:196-200.

52. van der Ploeg JR, Giertsen E, Lu“ din B, Mo“" rgeli C, Zinkernagel AS, Gmür R, 2004. Quantitative detection of Porphyromonas gingivalis fimA genotypes in dental plaque. FEMS Microbiol Lett. 232:31-37.

53. Socransky SS, Haffajee AD, Smith C et al. Use of checkerboard DNA-DNA hybridization to study complex microbial ecosystems. Oral Microbiol Immunol 2004;19:352-362.

54. Socransky SS, Smith C, Martin L, Paster BJ, Dewhirst FE, Levin AE. _Checkerboard_DNA-DNA hybridization. Biotechniques 1994;17:788-792.

55. Socransky SS, Haffajee AD, Cugini MA, Smith C, Kent RL Jr. Microbial complexes in subgingival plaque. J Clin Periodontol 1998;25:134-144.

56. Xime'nez-Fyvie LA, Haffajee AD, Socransky SS. Comparison of the microbiota of supra- and subgingival plaque in subjects in health and periodontits. J Clin Periodontol 2000;27:648-657.

57. Xime'nez-Fyvie LA, Haffajee AD, Socransky SS. Microbial composition of supra- and subgingival plaque in subjects with adult periodontitis. J Clin Periodontol 2000;27:722-732

58. Darout IA, Albandar JM, Skaug N, Ali RW. Salivary microbiota levels in relation to periodontal status, experience of caries and miswak use in Sudanese adults. J Clin Periodontol 2002;29:411-420.

59. Bostro"m L, Bergstro"m J, Dahle'n G, Linder LE. Smoking and subgingival microflora in periodontal disease. J Clin Periodontol 2001;28:212-219.

60. Haffajee AD, Socransky SS. Relationship of cigarette smoking to the subgingival microbiota. J Clin Periodontol 2001;28:377-388.

61. Haffajee AD, Bogren A, Hasturk H, Feres M, Lopez NJ, Socransky SS. Subgingival microbiota of chronic periodontitis subjects from different geographic locations. J Clin Periodontol 2004;31:996-1002.

62. Craig RG, Boylan R, Yip J et al. Prevalence and risk indicators for destructive periodontal diseases in 3 urban American minority populations. J Clin Periodontol 2001;28:524-535.

63. Feres M, Haffajee AD, Allard K, Som S, Socransky SS. Change in subgingival microbial profiles in adult periodontitis subjects receiving either systemically-administered amoxicillin or metronidazole. J Clin Periodontol 2001;28:597-609.

64. Sakellari D, Belibasakis G, Chadjipadelis T, Arapostathis K, Konstantinidis A. Supragingival and subgingival microbiota of adult patients with Down's syndrome. Changes after periodontal treatment. Oral Microbiol Immunol 2001;16:376-382.

65. . Paster BJ, Bartoszyk IM, Dewhirst FE. Identification of oral streptococci using PCR-based, reverse-capture, checkerboard hybridization. Methods Cell Sci 1998;20:223-231.

66. Choi BK, Paster BJ, Dewhirst FE, Go" bel UB. Diversity of cultivable and uncultivable oral spirochetes from a patient with severe destructive periodontitis Infect Immun 1994;62:1889-1895.

67. Spratt DA, Weightman AJ, Wade WG. Diversity of oral asaccharolytic Eubacterium species in periodontitis - identification of novel phylotypes representing uncultivated taxa. Oral Microbiol Immunol 1999;14:56-59.

68. Kroes I, Lepp PW, Relman DA. Bacterial diversity within the human subgingival crevice. Proc Natl Acad Sci USA 1999;96:14547-14552.

69. Sakamoto M, Umeda M, Ishikawa I, Benno Y. Comparison of the oral bacterial flora in saliva from a healthy subject and two periodontitis patients by sequence analysis of 16S rDNA libraries. Microbiol Immunol 2000;44:643-652.

70. Becker MR, Paster BJ, Leys EJ et al. Molecular analysis of bacterial species associated with childhood caries. J Clin Microbiol 2002;40:1001-1009.

71. Paster BJ, Falkler WA Jr, Enwonwu CO et al. Prevalent bacterial species and novel phylotypes in advanced noma lesions. J Clin Microbiol 2002;40:21872191.

72. Kazor CE, Mitchell PM, Lee AM et al. Diversity of bacterial populations on the tongue dorsa of patients with halitosis and healthy patients. J Clin Microbiol $2003 ; 41: 558-563$

73. Boches SK, Lee AM, Paster BJ, Dewhirst FE. Development of a Human Oral Microbe Identification Microarray. J Dent Res 2004;83(Spec Iss A): IADR 